\title{
ARE THERE ANY EARNINGS MANAGEMENTS OF ISLAMIC BANKING IN INDONESIA? (CASE STUDY OF ISLAMIC BANKING "X" AND "Y")
}

\author{
Banu Witono \\ Muhammad Sholahuddin (didinsolo@yahoo.com) \\ Faculty of Economics University of Muhammadiyah Surakarta
}

\begin{abstract}
The objective of this research is to analyze the possibility of Earnings Management in the financial statement of Islamic Banks. The population of research includes Islamic general bank. This research applied purposive sampling with Islamic general banks issuing financial statement within consecutive five years; 2002 - 2006. The hypothesis of the research is the Earnings Management in the financial statement of Islamic Banking. This research applied the method of Total Accrual Healy (1985) as described in Arfani and Sasongko (2005) to identify Earnings Management. Based on the test performed, the average total accrual for 5 years of research is positive and negative, thus, it can be concluded that there is Earnings Management in the financial statement of Islamic Banking in Indonesia as for case Islamic Bank " $X$ " and " $Y$ ".
\end{abstract}

Keywords: Islamic Bank, Financial Statement, Total Accrual, Earnings Management

\section{INTRODUCTION}

Islamic financial reporting and accounting system is designed to accommodate Islamic business economic system rooted in Al-Quran and Sunnah (Hadith). Allah says in the Al Quran "they weren't ordered but to worship Allah by purifying their compliance with Him in (complying) the religious commands and to do the prayers and tithe since it is the true religion" (QS Al Bayyinah:5); "And He is the one creating rulers on earth and He creates some of you at different classes to test you on what He has given you ..." (QS Al An'am:165).

The verses show that the essential objective of human being in their routine is to worship Allah. This covers the economic activities e.g. Islamic financial management. Based on the verses, the objective of Islamic financial management is accountability to Allah and others being legible to the company or nature. The parties who are entitled to the company may include financial statement users e.g. fund grantor, beneficiaries and recipients, tithe payer, shareholders, supervisory authorities, Bank Indonesia, Government, saving guarantor and public communities. Accountability is not merely an obligation to report the performance of economic activities and transactions, but also to carry out or not to carry out certain activities and transaction violating the Islamic rules (Kusumawati, 2005)

In practice, company owner is assisted and accompanied by the manager. The authority of fund management and decision taking is commonly vulnerable to create conflict of interest between the shareholders as the owner and managers as the controller of the company. The conflict of interest may also lead to a theory suggesting that individuals are motivated by their own interest. This theory was later known as agency theory (Anthony and Govindajaran, 1995 in Indah, 2006).

According to Archer and Karim (1997) agency theory is strongly relevant to Islamic Banking (Pramono, 2006). It bears correlation to the aspect of accountability and transparency of Investment Account Holder and company owner. First, in terms of liabilities, since Islamic Banking is accountable to various categories of investor fund through specific investment contract in Islamic Banking. Second, in terms of "assets" profit sharing - based financing applied by Islamic Banks demand effective "monitoring" to assure that the financed project is 
closely supervised and reports are delivered sufficiently to prevent from moral hazard and mismanagement such as profit manipulation.

Recalling the conflict of interest between the agent and principal, there is created the practice of Earnings Management (Anthony \& Govindarajan, 1995). Although Islamic Banking is operated in the system of profit sharing, there is possibility that Islamic Bank applies certain policy for Earnings Management. One of the Earnings Management policies is smoothening of profit and loss sharing deposit returns by providing incentives of return to Investment Account Holder comparable to the market rate as the benchmark. In addition, this policy is mostly applied by the bank management to allocate reserve fund sourced from the earlier accounting period. As a consequence, this situation will generate the potentials of asymmetric information for the Islamic Bank stakeholders. Looking at the background of issue described above, the research is focused as follows: Whether there is Earnings Management in the financial statement of Islamic Banking.

\section{LITERATURE REVIEW AND HYPOTHESES}

\section{Islamic Bank}

Pursuant to Law of the Republic of Indonesia Number 10/298 enacted on November 10, 1998 on Islamic Bank as "business entity collecting or raising fund from public communities in savings and distributing the fund to the public in financing and others schemes with Islamic principles". Banks plays its role in smoothening the economy by smoothening the flow of fund from the parties with fund surplus to the parties needing the fund.

In general, recalling the pricing method, bank is classified into two types; conventional bank and Islamic Bank. Islamic Bank means bank which, during the course of operations, either collecting fund for distribution will provide compensation in Islamic principles that is sale and purchase and profit sharing (Sholahudin, 2006).

The ground of Islamic Bank is the excessive interest in conventional bank in the operations. In Al Quran and Sunnah, excessive interest is strongly prohibited due to its tyranny (Q.S Al Baqoroh: 283) and opinions of the Islamic teachers forbidding such excessive interest.

The fundamental differences of conventional and Islamic Bank is presented in the following table:

Table 1. Difference of Islamic Bank from Conventional Bank

\begin{tabular}{|l|l|}
\hline \multicolumn{1}{|c|}{ Islamic Bank } & \multicolumn{1}{|c|}{ Conventional Bank } \\
\hline 1. Lawful Investment & 1. Lawful and forbidden investment \\
\hline $\begin{array}{l}\text { 2. Applying profit-share scheme, sale } \\
\text { and pirchase or rent }\end{array}$ & 2. Applying interest \\
\hline 3. Profit dan falah oriented. & 3. Profit oriented. \\
\hline $\begin{array}{l}\text { 4. Relation to Customers in Partnership } \\
\text { 4. Relation to customers in debtor- } \\
\text { creditor }\end{array}$ \\
\hline $\begin{array}{l}\text { 5. Fund collection by instructions of } \\
\text { Islamic Supervisory Board }\end{array}$ & 5. Similar board is non-existent \\
\hline
\end{tabular}

Source: Islamic Economic Lesson Book (Sholahudin, 2006) page 88

Similarly to conventional bank, Islamic Bank also offers various banking products and services in Islamic values e.g.

1. Al Wadiah/Savings (Guidance of National Islamic Board DSN No: 02/DSN/MUI/IV/2000) Al Wadiah means savings kept in Islamic Bank, basically saving of one party with another, both individuals and legal entities to be properly kept and returned at any time should the owner wish to.

Nevertheless, in line with the progress, savings which apply yad al-manah by which the bank 
as the beneficiary is allowed to utilize the fund as deposit saving, saving and future deposit for the purposes of public communities and State, the most important is that the saver is fully liable to the loss and damage.

3. Share-Profit Financing:

a. Al-Musyarakah (Guidance DSN no: 08/DSN-MUI/IV/2000) means cooperation agreement made and entered into between two parties or more pursuant to which each party grants contribution of fund (capital) on condition that the profit and risks will be jointly borne as earlier agreed with.

b. Al-Mudharabah (Guidance of DSN no: 07/DSN-MUI/IV/2000) is a cooperation agreement made and entered into between two parties or more pursuant to which the party (malik, shahib al-maal) will make the investment, while the second party ('amil, mudharib, customer) will act as manager and the profit will be shared between or among them as agreed to and contemplated in the contract.

c. Al-Muzaro'ah means cooperation agreement on agricultural undertaking between the land owner and cultivator (Hakim., 2007).

d. Al-Musaqah is a simplified form of al-muzara'ah, where the cultivator is only responsible for watering and cultivating and for the compensation, cultivator is entitled to the particular ratio of profit generated from the harvest (Hakim., 2007).

4. Bai'al-murabahah (Guidance of DSN no: 04/DSN-MUI/IV/2000) selling goods by confirming the price of purchase to the buyer and buyer will pay the higher price as profit.

5. Bai'as-salam (Guidance of DSN no: 05/DSN-MUI/IV/2000) Sale and Purchase of Goods by ordering and advance payment on specific terms and conditions"

6. Bai'al-istishna (Guidance of DSN no: 06/DSN-MUI/IV/2000) Specific form of bai'as-salam, therefore, the terms and conditions in bai'al-istishna complies with the terms and conditions of bai'as-salam. Bai'al-istishna is defined as sale and purchase agreement in order to produce goods with specific criteria agreed between the ordering party (buyer, mustashni') and seller (manufacturer, shani')

7. Al-wakalah/amanat (Guidance of DSN no: 10/DSN-MUI/IV/2000) Agreement on Delegation of Authorities by a party to the other party for assignable purposes.

8. Al-kafalah/warranty (Guidance of DSN no: 1 I/DSN-MUI/IV/2000) Warranty Agreement issued by the Guarantor (kafiil) to any third party to fulfill the obligations of the second party or secured party (makfuul 'anhu, ashil).

9. Al-hawalah (Guidance of DSN no: 12/DSN-MUMV/2000) Agreement on Debt Assignment of an indebted party to a party to pay the debt

10. Ar-rahn (Guidance of DSN no: 25/DSN-MUI/III/2002) means the act to hold the assets of the borrower as security to the loan received

\section{Agency Theory}

According to Anthony \& Govindarajan (1995), the word "agent" means mechanism generated by manufacturing or business company. In essence, the function of agent is correlated to the relations of rules applied. Anthony and Govindarajan (1995) suggested the assumption of agency theory that each individual is solely motivated by his/her own interests potentially creating conflict of interest between the principal and agent. Principal is motivated to make the contract to take benefits with increasing profitability, while the agent is motivated to maximize the fulfillment of economic and psychological needs (Indah, 2006).

Based on the above definition, it is concluded that manager and owner will have conflict of interest due to which most companies will undergo agency problem. Crutchley and Hansen (1989) expressed that agency problem occurs due to separation of control and management of the company. Separation occurs because the shareholders and diversification of portfolio delegating the authorities in financial affairs and decision taking to the corporate managers (Gunarsih, 2004). Delegation of authorities to manage the owner's fund and decision taking in the company will potentially create conflict of interest between the owner and manager as the company controller. The owner bears the interest in diversification of systematic risk of the company, meanwhile, managers will have the tendency to fulfill their own interests as may 
possibly contravene to the owners'. For example, a manager may enjoy extra income at the expense of the owner, manager may possibly adopt decision on short-term operating costs advantageous to the manager but harmful to the owner and manager may decide the activities to minimize the risk although the company risk toward to the owner increases.

Agency problem between the owner and manager will create equity agency cost. According to Jensen and Meckling (1976) there are three types of agency cost, monitoring cost by the principal, bonding cost by the agent and residual loss. Monitoring cost is incurred by the principal to limit the activities of agent as different from the interest of the principal (Gunarsih, 2004).

According to Jesen \& Meckling (1976) in Gunarsih (2004), agent will need to expend bonding costs to assure the principal that the agent will not take certain actions harmful to the investor. One example of bonding cost is the costs incurred by the owner-manager to assure the equity holder that manager will limit the activities generating non-pecuniary benefits for the manager. Forms of the costs include the assurance that financial statement is audited by certified public account, explicit assurance on abuse of manager's authorities and limitation to the authorities of decision taking by the manager. This limitation will require the costs for limiting the manager's skills to make use of advantageous opportunities as on limitation causing loss to the owners and advantageous only to the manager.

Earlier Studies

Earnings Management is presently debatable among parties on the ethic of application. Nevertheless, many companies apply Earnings Management aimed at improving the corporate performance.

Study on the existence of Earnings Management in the financial statement was conducted by some researchers. Research conducted by Kiswara (1999) on the indicators of Earnings Management in the financial statement of public company. Sutanto (2000) studied on the indicators of Earnings Management in anticipation of IPO by the companies registered with JSE and Lidyah (2002) studied on indications of Earnings Management on performance of SEO. Gumanti (2003) in the research entitled "Earnings Management in Initial Public Offering with Jakarta Stock Exchange, examining the accounting decisions taken by the company for go public before the shares are exchanged with the stock exchange or examining whether earning management occurs in the initial public offering in Indonesian Capital Market. The results of examination on 39 IPO companies for go public between 1995 and 1997 applying total accruals demonstrated strong evidence of the earnings management, particularly two years before go public. This implies that issuers have elected accounting method increasing the reported earnings by applying income-increasing discretionary accruals.

Sulistyanto and Prapti (2003) examined "Stock Options, Supporting Opportunist Managers? Discovering that post stock option, company will undergo improved performance starting from the year of stock option until two years after such event. This research managed to prove that improved performance after the post option is attributable to the executive's manipulating the earning management $y$ income increasing model shown by the positive discretionary accruals. This is a reflection of the attitude of opportunist managers to boost the performance by maximizing the value of shares.

Research on Good Corporate Governance conducted by Sulistyanto and Wibisono (2003) discovered that management selected the items of fixed and long-term assets as the basis for financial changes. In addition, the research also demonstrated that management applies earning management by income decreasing to manipulate what indicated on the negative discretionary accruals.

Research on earning management was also performed by Arfani and Sasongko (2005). They 
analyzed the difference of earnings management on the status of loss and profit of manufacturing company in Indonesia. They found that financial statements of public company both gaining profits and suffering losses actually apply earning management. If the value of mean discretionary accrual is positive, earnings management is performed by increasing the earnings figure in the financial statement, meanwhile, if it is negative, earnings management is performed by decreasing the figures of earnings in the financial statement. In the research, the company which implement earnings management by increasing the earning figures in the annual statement that is company suffering loss and company gaining profits by decreasing the figures of earnings in the annual financial statement. In the annual financial statement, there is significant difference of earnings management between company gaining profits and suffering losses.

The theory exposition above cited that Islamic bank is bank, which in the course of operations, collecting the fund and distributing the fund, impose compensation on the basis of Islamic principles that is sale and purchase and profit share. (Sholahudin M., 2006). In practice, the owner is assisted by the company managers. By the authorities to manage the owner's fund and other decision takers will create conflict of interest between the owner and manager as company's controller.

Hypothesis

Based on literature review and perspective above, research hypothesis can be proposed as follows: "There is earnings management in the Islamic bank financial statement in Indonesia"

Figure 1. Research Theoretical Outline

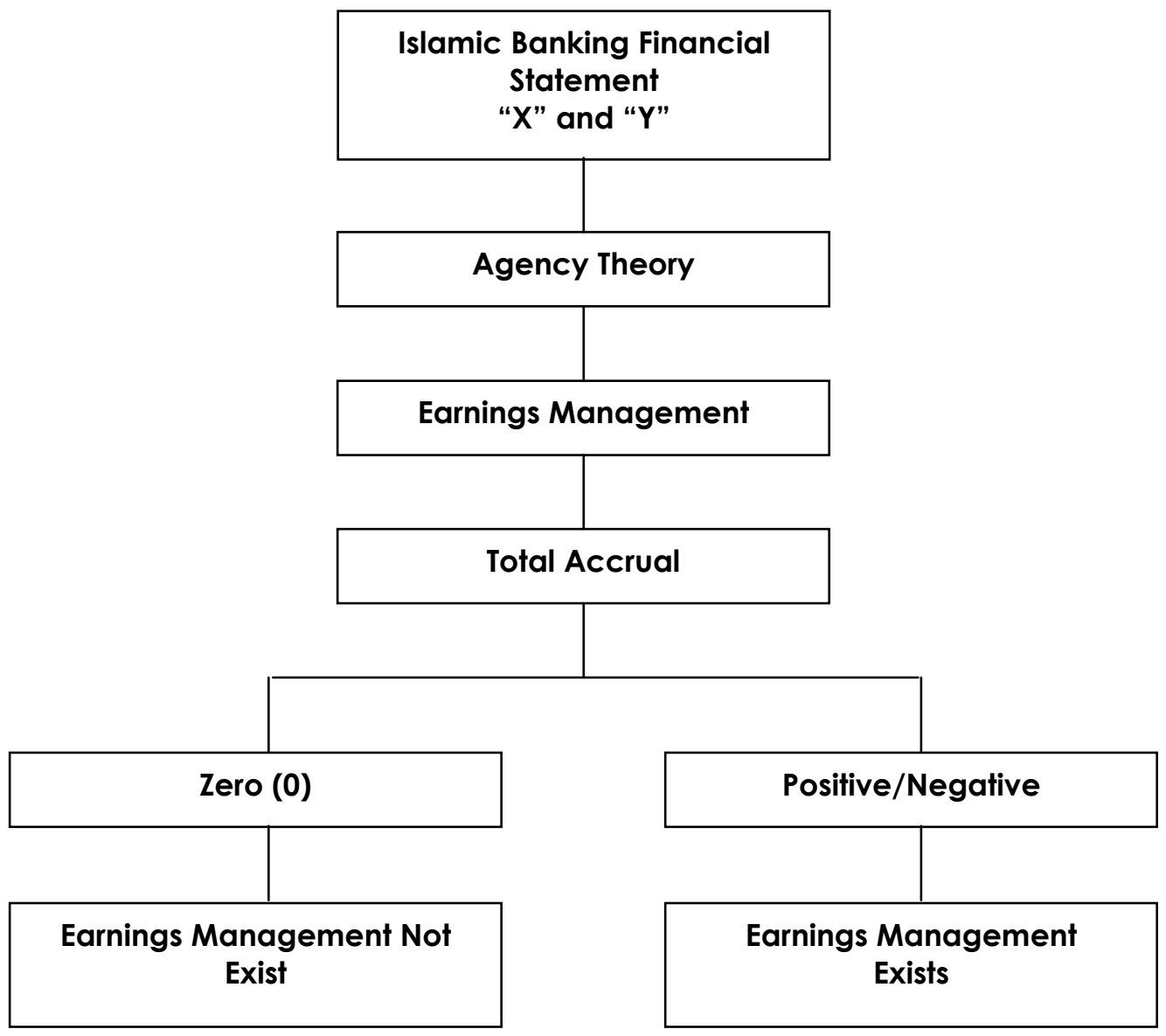




\section{RESEARCH METHOD}

Perspective (Mind Frame)

Archer and Karim (1997) suggested that although theoretically Islamic bank operates through profit-share system, there is possibility that Islamic bank applies earnings management policy (Pramono, 2006). This is closes related to the accountability and transparency of Investment Account Holder (IAH) and company's owners.

To detect the application of earnings management, estimates of earnings on accrual is regarded as highly important. Total accrual means all operational events within one year affecting the cash flow. Earnings management can be identified from the positive or negative mean total accruals. Positive mean total accruals means that Islamic bank manage the earnings by increasing the figures in the reported earnings meanwhile negative mean total accruals means Islamic bank manage the fund by decreasing the earnings.

To further clarify the objectives and discussion, the present research is limited to:

1. Research is performed in two Islamic Banks in Indonesia publishing financial statement within each period of fiscal year ended December 31.

2. Interval of research from 2002-2006.

\section{Variables Measurement}

1. Research Variables and Measurements

a. Total Accrual

Total Accrual means all operational events in one year affecting the cash flow (Arfani and Sasongko, 2005).

b. Changed Cash Flow

Cash means cash fund in paper or metal and other instrument of payments equalized to cash fund (Arifin and Fakhrudin, 1999)

Change of cash means balance of cash in period t compared to the earlier period.

$\triangle$ Cash $=$ Cash $_{\uparrow}-$ Cash $_{t-1}$

c. Change of Current Assets

Current asset means each asset in the short-term balance sheet convertible to cash fund e.g. cash fund, receivables and stocks usually considered as having term of one year or lesser (Arifin and Fakhrudin, 1999).

Change of current assets means balance of current assets in period t to the earlier period.

$\triangle C A=C A_{t}-C A_{t-1}$

d. Change of Current Liabilities

Current liabilities mean balance liabilities due short time, usually one year or less e.g. operating debt and tax liabilities.

(Arifin and Fakhrudin, 1999).

Change of current liabilities means the balance of current liabilities in period t to the earlier period

$\Delta \mathrm{CL}=\mathrm{CL}_{\dagger}-\mathrm{CL}_{\uparrow-1}$

e. Change of Long-term Debt included in the Current Debt

Long-Term debt classified as current debt means balance obligations due long-term which settlement will cover a period longer than one year (Arifin and Fakhrudin, 1999).

Change of Long-Term Debt means the balance of long-term debt in period t to the earlier period.

$\triangle S T D=S T D_{\dagger}-S_{T} D_{\dagger-1}$

f. Depreciation costs

Depreciation costs mean the allocation process of fixed asset price to costs during the useful life resulting from use/wear acknowledged in the accounting system and income tax Arifin and Fakhrudin, 1999). 
g. Total Assets

Total assets means all economic sources owned and controlled by the company usually denominated in money. Types of economic sources is called company's assets or called cash, receivables, land, building, machineries and et cetera (Arifin and Fakrudin, 1999).

2. Hypothesis Test

Earnings management can be measured by total accrual. Total accrual means the proxy of accrual policy implemented by the corporate management. This research applies the formula of total accrual suggested by Healy as in Arfani and Sasongko (2005) that is:

TA $A_{\text {it }} \quad:$ Total Accruals bank $\mathrm{i}$ in period $\dagger$

$\triangle C A_{\text {it }} \quad:$ Change of bank current assets $\mathrm{i}$ in period $\dagger$

$\triangle C_{\text {lit }} \quad$ : Change of bank's current debt $\mathrm{i}$ in period $t$

$\triangle$ Cashit: Change of bank cash and cash equivalents i in period $t$

$\triangle S T D_{i t} \quad$ : change of long-term debt covered in bank current debt $\mathrm{i}$ in period $t$

Depit $\quad$ : Bank depreciation costs i in period $t$

$A_{(i t-1\}} \quad:$ Total bank assets $i$ in period $t$

This research does not include the account of long-term debt due immediately since not all samples specify the account:

Testing Criteria

a. Hypothesis is accepted if $\mathrm{TA}<0$ or $\mathrm{TA}>0$, implying that there is earnings management in the financial statement of Islamic bank.

b. Hypothesis is rejected if TA - 0, implying that there is no earnings management in the financial statement of Islamic bank.

\section{RESULTS AND DISCUSSION}

To elucidate the description of samples applied, below is descriptive statistics of the companies selected as samples.

Table 1. Sample Descriptive Statistics ( $n=2)$

\begin{tabular}{|c|c|c|c|c|c|c|}
\hline Year & $\Delta \mathrm{CA}_{\text {it }}$ & $\Delta \mathrm{CL}_{\text {it }}$ & $\Delta$ Cashit & Deprit & $A_{i t-1}$ & TA $A_{i t}$ \\
\hline 2002 & 405554 & 899260 & -55127 & 14060 & 3756590 & 0.78319 \\
\hline 2003 & 1421176 & -1774570 & 248582 & 22150 & 6730985 & 0.43456 \\
\hline 2004 & 1195971 & 1000150 & 404396 & 29980 & $1.2 \mathrm{E}+07$ & 0.39769 \\
\hline 2005 & 1331320 & 377535 & 68691 & 44338 & $1.6 \mathrm{E}+07$ & 0.23432 \\
\hline 2006 & 1597531 & 375735 & 70682 & 45764 & $2.0 \mathrm{E}+07$ & 0.52675 \\
\hline
\end{tabular}

Source: Processed Primary Data

Note:

- The value of change of current assets ( $\Delta C A_{\text {it }}$ ), change of current debt ( $\Delta C$ Lit $_{\text {it }}$, change of cash $\left(\Delta\right.$ Cash $\left._{\text {it }}\right)$, depreciation (Deprit) and total assets $\left(A_{i t-1}\right)$ are presented with figures rounded in million Rupiahs)

- The value of total accrual is presented in normal figure

The value of current assets, current debts, cash, depreciation and total assets are generated from the value of the financial statement of sample companies. Financial statement applied is audited and forming full and complete financial statement for one year.

As earlier cited, this research applies total accrual to measure whether earnings management is applied in the financial statement of Islamic bank. This research applies the formula of Total Accruals suggested by Healy (1985) in Arfani and Sasongko (2005).

By looking at the table total accrual model of Healy (Table 2) it is identified that Islamic bank 
" $X$ " and " $Y$ " applies earnings management. This is indicated from the positive and negative total accrual.

From the table, the average total accrual applying Healy model (Table 2), it is shown that the mean total accrual and Islamic bank in 2002, 2004, 2005 and 2006 is positive. Meanwhile, in 2003, mean total accrual of Islamic bank is negative. This implies non existence of earnings management in the financial statement of Islamic bank. Positive mean total accrual means Islamic bank applies earnings management by increasing the reported earnings. On the contrary, negative mean total accrual shows that Islamic banking performs earnings management by decreasing the profit.

Table 2. Mean total accrual (Healy Model)

\begin{tabular}{|c|c|}
\hline Year & Total Accrual \\
\hline 2002 & 0.3987 \\
\hline 2003 & -0.0564 \\
\hline 2004 & 0.2185 \\
\hline 2005 & 0.1273 \\
\hline 2006 & 0.1652 \\
\hline
\end{tabular}

Source: Processed Primary Data

In 2003, the value of total accrual of Islamic Bank "Y" was negative implying that Islamic Bank " $Y$ " performed earnings management by decreasing the profit. There are possibilities related to the issue. One of them is related to the effective statement of the Chairman of BAPEPAM by Letter No. S 2545/PM/2003 dated 22 October 2003. The letter stated that on 22 October 2003 Islamic Bank " $Y$ " is allowed to organize public offering of mudharabah Islamic bond at nominal value of Rp. 200.000.000.000,00. As per such letter, then as of 3 November 2003, the outstanding bond has been registered with Surabaya Stock Exchange.

Based on test performed for five years of observation on mean total accrual, Islamic bank owns lower and greater than 0 , thus, it is concluded that there is earnings management in the financial statement of Islamic bank. This implies that hypothesis indicating the earnings management in the financial statement of Islamic banking: is accepted.

\section{CONCLUSIONS}

\section{Conclusions}

Based on tests performed during the observation period, it is concluded that in the financial statement of Islamic bank, there is earnings management. This is made evident by the computation of mean total accrual for five years of observation as positive and negative.

Mean total accrual during five years of observation is $0.3987,-0.0564,0.2185,0.1273$, and 0.1652 . Mean positive total accrual shows earnings management in the financial statement of Islamic banking by increasing the earnings. On the contrary mean negative total accrual shows that there is earnings management in the financial statement of Islamic bank by decreasing the earnings.

Based on the results of complementary tests, it is concluded that variables may potentially affect earning management include company's size, leverage and profitability is not affecting.

\section{Limitations}

There are limitations in the research, thus further recommendation can be made in the future. Limitations include: 
a. insufficient samples of research to represent all, subsequent research must add samples. b. This research applies the formula of total accrual of Healy model in Arfani and Sasongko (2005), subsequent research must be added with another formula as comparison and revision to this paper. Another formula to be applied includes Jones and Jones modification in Arfani and Sasongko (2005). Jones model develops the model to distinguish discretionary accrual and nondiscretionary accrual. Jones in Arfani and Sasongko (2005) applies the income and fixed assets to proxy the level of normal accrual. The existence and non-existence can be identified through the value of discretionary accrual by decreasing total accrual and nondiscretionary accrual. Jones modification is fundamentally similar to Jones model, but the earlier includes the operating receivables to decrease the income.

\section{Implication}

a. The outcome of the research bears implication on investors to select the companies to invest their fund. To identify the existence or non-existence of earnings management in the financial statement, investors may observe the total accrual. Investors is expected to avoid company having positive or negative total accruals since it means financial statement of the company contains earnings management.

b. The outcome of complementary test in this research shows that the variables potentially affecting the earnings management are factually not significantly in effect but partially. This creates opportunity for the subsequent research to study the variables which may affect earnings management.

\section{Recommendations}

Islamic bank should not perform the practices of earnings management since it will produce misleading and inaccurate information on the actual status of the company. This contravenes the Islamic principles. To avoid the practice of earnings management, one of the measures to adopt is to establish a competent and proactive Islamic Supervisory Board (DPS)

\section{REFERENCE}

Astri Arfani NK dan Noer Sasongko, 2005. Analisis Perbedaan Pengaturan Laba (earning management) pada Kondisi Laba dan Rugi pada Perusahaan Manufaktur di Indonesia, Jurnal Akuntansi dan Keuangan, vol. 4, No. 1, April 2005, Hal. 1 - 20.

Djarwanto, 2000. Statistik Induktif, Edisi Keempat, BPFE, Yogyakarta.

Endang Kiswara, 2005. Indikasi Keberadaan Unsur Manajemen Laba (Earning Management) dalam Laporan Keuangan Perusahaan Publik, Tesis pada Fakultas Ekonomi Universitas Gajah Mada, Yogyakarta.

Intan Imam Sutanto, 2000. Indikasi Manajemen Laba menjelang IPO oleh Perusahaanperusahaan yang terdaftar di BEJ, Tesis pada Fakultas Ekonomi Universitas Gajah Mada, Yogyakarta.

Johar Arifin dan Muhammad Fakhrudin, 1999. Kamus Istilah Pasar Modal, Akuntansi, Keuangan dan Perbankan, Gramedia, Yogyakarta.

Mayasari Indah, 2006. Persepsi Manajer dan Internal Auditor terhadap Pertimbangan Etika dalam Praktik Manajemen Laba, Skripsi pada Fakultas Ekonomi Universitas Jenderal Soedirman, Purwokerto.

Muhammad, 2005. Pengantar Akuntansi Syariah, Edisi Kedua, Salemba Empat, Jakarta.

Muhammad Syafi'l Antonio, 2001. Bank Syariah dan Teori ke Praktik, Gema Insani, Jakarta.

Nur Indriantoro dan Bambang Supomo, 2002. Metodologi Penelitian Bisnis, Edisi Kedua, BPFE, Yogyakarta.

Rika Lidyah, 2002. Analisis Indikasi Earning Management terhadap Kinerja pada SEO, Tesis pada Fakultas Ekonomi Universitas Gajah Mada, Yogyakarta.

Sigit Pramono, 2006. Permasalahan Agency Theory dan GCG pada Perbankan Syariah, Media Akuntansi, Edisi 52 Januari 2006. 
Sri Sulistyanto dan Haris Wibisono, 2003. Good Corporate Governance : Berhasilkah Diterpakan di Indonesia? Jurnal Widya Warta, No. 2 Tahun XXVI/Juli 2003, ISSN : 08541981.

Sri Sulistyanto dan Meniek S. Prapti, 2003. Stock Options : Berhasilkah Mendorong Manajer Oportunis? Jurnal Akuntansi dan Bisnis, vol. 1, No. 2, Maret 2003, ISSN : 1412 - 775x.

Sugiyono, 2006. Statistika untuk Penelitian, Edisi Kesembilan, ALFABETA, Bandung.

Sukma Indah R., 2005. Pengaruh Leverage, Ukuran Perusahaan dan Profitabilitas terhadap Manajemen Laba, Skripsi pada Fakultas Ekonomi Universitas Jenderal Soedirman, Purwokerto.

Suliyanto, 2005. Analisis Data untuk Riset Pemasaran, Ghalia Indonesia, Bogor.

Suyatmin dan Arfan Ikhsan, 2003. Masalah Agency Theory dalam Perusahaan : Suatu Tinjauan terhadap kontrak bisnis dalam Konteks Islam, BENEFIT, vol.7, No.2, Desember 2003, Hal. $142-166$.

Tatang Ari Gumanti, 2000. Earnings Management : Suatu Telaah Pustaka, Jurnal Akuntansi dan Keuangan, vol.2, No.2, Nopember 2000, Hal. $104-115$. 2001. Earnings Management dalam Penawaran Saham Perdana di Bursa Efek Jakarta, Jurnal Riset Akuntansi Indonesia, vol.4, No.2, Mei 2001, Hal. 165 183.

Tri Gunarsih, 2004. Masalah Keagenan dan Strategi Diversifikasi, KOMPAK, No.10, Januari April 2004, Hal. 52 - 69.

Ummi Arifa Afni dan John JOI Lhalauw, 2002. Manajemen Earning dalam Penawaran Perdana Saham, Jurnal Ekonomi dan Bisnis, vol.VIII, No.2, September 2002, Hal. 191 208.

Wiwiek Prihandini, 2003. Manipulasi Data Akuntansi dalam Earning Management, Diskusi Dosen STIE PERBANAS, Bandung.

Zaidah Kusumawati, 2005. Menghitung Laba Perusahaan Aplikasi Akuntansi Syari'ah, Magistra Insania Press, Yogyakarta.

Noname, 2003. PSAK, IAI, Jakarta.

M. sholahudin, 2006. BukU Ajar Ekonomi Islam, UKM KEI FE UNS \& Pusat Studi Ekonomi Islam UMS, Surakarta.

Lukman Hakim, 2007. Buku Ajar Lembaga Ekonomi dan Keuangan Syariah, Universitas Muhammadiyah Surakarta, Surakarta.

www.muamalatbank.co.id

www.syariahmandiri.co.id 